\title{
70th Meeting of the Association of
}

\section{Research Libraries}

The 70th meeting of the Association of RESEARCH Libraries, held in San Francisco on June 24, was opened at 2 p.m. by ARL President Rutherford D. Rogers (Stanford University Libraries). After greeting and introducing new members and guests, Mr. Rogers presided over the program session, which was devoted to three papers and a panel discussion of "The Ideal National Library." Referring to the Library of Congress as "the greatest de facto national library in the world," he stressed the importance of its role, especially in view of the deliberations and forthcoming recommendations of the National Advisory Commission on Libraries.

Stuart Forth (University of Kentucky) was the first speaker. In discussing "Resources," he mentioned the love-hate relationship that a poorer library has with LC. "If not the ideal national library, LC is a very intimidating institution," he said, "and most of us feel that it ought to be doing things for us." Among other things, a national library should collect comprehensively; but no matter how much material is acquired, the scholarly world always wants more, he observed, and he quoted the British Museum's great Panizzi as defining necessary materials as information from all countries, no matter in what form or language, essential to keep pace with the growth of knowledge. LC seems to be making an effort to collect on this scale, he said. By the standards of the world, LC's collections are rich. But a national library's resources are also people, services, and special collections, and $\mathrm{Mr}$. Forth suggested that LC make its subject specialists available to other libraries-that it create a kind of bibliographic peace corps to help others to learn what they ought to do. Even an occasional loan of a specialist would be helpful, he said. "Now we hire one another, or a computer-type, or a managementtype."

Most of our librarians are humanists and social scientists and expect the scientific community to take care of scientists, Mr. Forth observed, but "our own national library, LC, is damned and panned for its subject headings by the scientists." A determined effort to keep subject headings apace with advances in research should be made. Also, LC should certainly take the lead in automation. It should also serve as the national lending library. In short, he declared that "most of us feel that LC's resources would be more readily available to us if LC were in law as well as in fact the national library of the United States."

Warren J. Haas (University of Pennsylvania), in speaking on "Bibliographic Control," said that the library community wants a continuation, extension, and improvement of what LC as the national library is now doing. First, he felt that the quantity and quality of descriptive cataloging should be improved. The worldwide output of recorded information and knowledge in all subjects-without limitation as to form, language, or the size of the edition-should be identified and each item should be described according to Anglo-American Cataloging Rules. This bibliographic data should be available at the same time the item described becomes generally available. There must be consistency of practice as well as a high level of editorial quality, including correct and liberal use of added entries. Title II-C of the Higher Education Act is a mandate to LC to take over cataloging responsibility for the country, he said, and the data must therefore be reliable, full, and free of errors.

In regard to the distribution of cataloging information, Mr. Haas urged that the "cataloging in source" concept should be applied where possible. He felt that federal, state, and local documents could be processed with state library assistance, that dissertations and university press publications could be cataloged with university library assistance, etc., and that the information could be included in the book itself. There should be automatic and prompt distribution of catalog information, with libraries having a choice of all catalog information produced by the national library or only information in specified categories, such as selected subjects or certain languages. Mr. Haas also thought that a code number should be used to relate the pertinent bibliographic information to the item itself, that it should be included as part of the catalog data, and that it could be used in retrieving bibliographic information. "The code system should enable individuals, working independently," he said, "to easily generate the same number for a given item."

The classifisation system should be geared to the nature of the subjects classified and should be sufficiently flexible to reflect major changes in the orientation of the subjects themselves, Mr. Haas said. Alternate classifications should be provided in the basic 
bibliographic record. Subject headings should be reviewed and updated, and the subjectheading structure for any given field should be in sufficient detail or depth to satisfy the requirements of researchers in the field.

Mr. Haas suggested that a national library should (1) assume responsibility for the bibliographic control of recorded information produced in its own country, without exception, and that, if it cannot perform all the work, it should delineate that portion of the work that it can do and "should see to it" that the rest is done by other appropriate agencies in accordance with established standards of quality and speed; (2) energetically promote international coordination of bibliographic activities; (3) move quickly to set standards-for example, prepare transliteration rules, procedures for encoding bibliographic information for computer processing, and the like; (4) develop a system of communications between those responsible for bibliographic control and those making use of the records produced in order that governing policies may be understood on the one hand and user needs effectively transmitted on the other, but a "structure for federal backing is necessary"; and (5) assume responsibility for training individuals in descriptive and subject cataloging, indexing, and other bibliographic work by running regional training programs, producing specialized training manuals, and utilizing technical aids to education (such as programed learning and closed circuit television), thus spreading the expertise available in the national library.

Foster Palmer (Harvard University) discussed what special and auxiliary services a national library should have, assuming adequate resources and bibliographic controls. $\mathrm{He}$ advocated a very strong reference service, but raised the question of who should be the beneficiary. If even a national library tries to be all things to all comers, it might spread its resources too thin. Ideally, the national library should serve as the backstop when service is not available elsewhere in the country. It is easy to dismiss loan service as "old hat," he said, and its importance will decline as facsimile transmission becomes feasible, but meanwhile it is very essential. Federal departments would participate in this service, but the national library should have an "equalizing role" in the federal government.

Photocopying services supplying promptly inexpensive texts and illustrations, including color, should be available in the national library. Mr. Palmer recognized, however, the problem of copyright. He stressed that administrative practices are important, and he felt that the national library should attempt to liberalize access, with due regard to the rights of the holder of the copyright. Nevertheless, it was his view that the national library should be the agent of the information-seeking public.

The national library should also take the lead in establishing standards, formats, and systems for utilizing computer technology, Mr. Palmer asserted, consulting, of course, with other libraries. A start should be made by converting the bibliographic records to machine-readable form. It is reasonable to begin with current intake, but retrospective materials should be covered. This master bibliographic record of library holdings should be able to be used in a variety of ways through a network. Access to this information should not necessarily be free, but the cost of transmission should be cqualized and should not be related to geography-to the distance from the central memory store. This is an attainable goal, Mr. Palmer felt, "if the holders of the purse strings can be convinced." It will be costly but it should be regarded as a national investment. A further goal is instantaneous transmission of text, but, even when one is talking of an ideal national library, this is not now economically feasible. When it does become feasible, he concluded, the national library should take the leadership in developing it (with due regard for the copyright problems involved) for the nation's libraries and their users.

The panel consisted of Robert H. Blackburn (University of Toronto), Douglas W. Bryant (Harvard University), Ralph E. Ellsworth (University of Colorado), and L. Quincy Mumford (Library of Congress). Mr. Mumford, emerging from under the microscope-for no matter how tactfully the subject of the session (The Ideal National Library) was stated, it was LC that was being examined-opened the discussion. He emphasized that LC could endorse most of what had been said. It is already doing a great deal, but obviously it could do what it is doing better, and it could do more with greater resources. The Title II-C National Program for Acquisitions and Cataloging is bringing in increasing numbers of important publications from around the world, and the cataloging of these foreign materials, through shared cataloging and by LC's own augmented staff, has been speeded up. Although he felt that it would be utopian to expect that errors would never be made, especially in a crash cataloging program, the highest possible quality of work should always be the objective.

The MARC Pilot Project for the distribution of machine-readable bibliographic data on tape has almost completed the experimental stage and a revised format, MARC II, will soon be announced; the tapes, covering some foreignlanguage materials as well as those in English, will be sold regularly, along with printed catalog cards, through the Card Division. Meanwhile, the automation of the central biblio- 
graphic record, an exceedingly complex undertaking, is proceeding according to plan. The application of computer technology would, $\mathbf{M r}$. Mumford felt sure, permit more added entries, more subject coverage in depth, as well as the possibility of retrieving bibliographic data in a variety of forms. As for LC's taking the leadership in automation, it is not only willing, it is committed to this.

The three national libraries-the National Agricultural Library, the National Library of Medicine, and LC-have joined forces, have formalized and intensified long-standing cooperation between the three institutions, Mr. Mumford reported. A major objective will be to make their systems of automation easily convertible, if not compatible, and to create at LC a common data bank for national use. The difficult problem of subject headings will be given special attention. The three institutions have already joined in sponsoring and partially funding the first phase of the fourphase National Serials Data Program to develop a comprehensive set of data elements for serials and finally an automated system, centered in LC, to make that information available. LC will serve as the executive agent and the Joint Committee on the Union List of Serials will be an advisory group. The Council on Library Resources has made an initial grant and further subsidy is being sought from the National Science Foundation.

All these developments point up LC's role as the national library and the center for assistance to other libraries, a role to which LC is dedicated, Mr. Mumford said, and he agreed that recognition in law of $\mathrm{LC}$ as the national library would help. In regard to "exerting leadership," about which there is much talk, Mr. Mumford pointed out that it is not simply a matter of LC's presenting national needs to the Congress with requests for funds. The libraries of the nation must make their needs known, not only to LC but to their representatives in Congress. The national need must be felt before Congressional support for new programs can be expected.

Mr. Bryant stressed the importance of the collections as resources. "The national libraries of the United States are truly encyclopedic, rather than being concerned just with the publications of their own country or by their own nationals," he said. The national library should be strong in retrospective materials as well as in current publications, now being acquired more broadly under Title II-C, but a program for the acquisition of retrospective materials, while of great importance to scholarship,

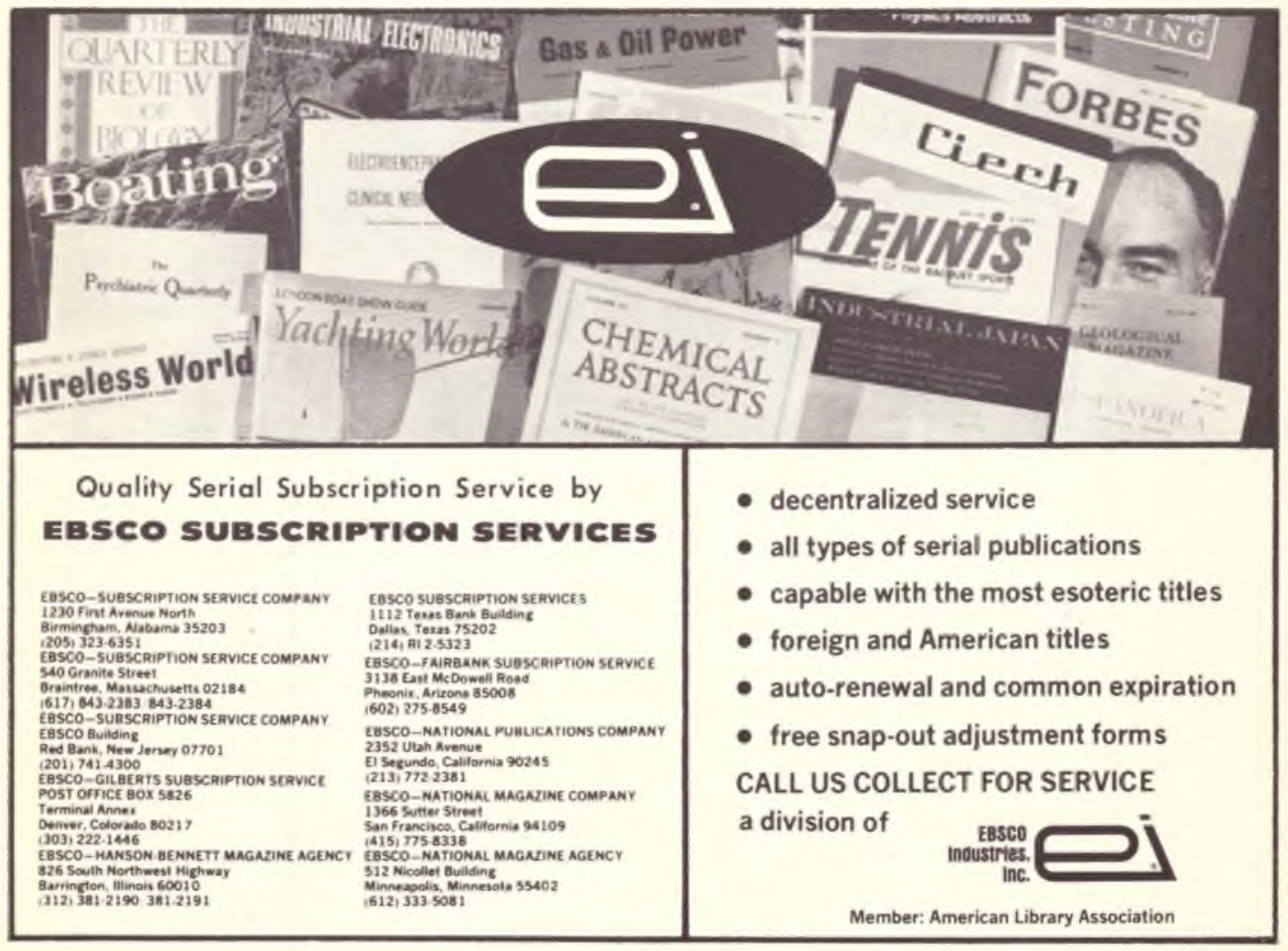


"would have less sex appeal politically," he recognized. Both libraries and scholars should be able, nevertheless, to look toward the national library for core collections. Furthermore, he said, the apparatus for automation must be centered in LC and be available to the entire country.

Mr. Blackburn described the activities of the Canada Council in support of libraries. Direct grants of $\$ 500,000$ are being made for collections of national importance, he said, and the central government is now giving each province 50 per cent of the operating costs of each university. The new National Library in Canada has responsibility for developing a plan for sharing resources and services, he reported. The Canadian National Research Council has been designated as responsible for science, but other agencies not designated have budget difficulties and consequently those who would use them also have a problem.

Looking at Washington, Mr. Blackburn saw, and was encouraged by, the "growing together" of LC, NLM, and NAL. He agreed that all forms of materials should be collected by the national library and should be generally available. He felt that in the matter of sharing staff resources, sending staff out on loan would not cover all needs. Instead he advocated scholarships for subject specialists to study library science. Finally, he said that a national library also has to be an international library; LC is pointing the way and he hoped for extensive cooperation with Canadian libraries.

Mr. Ellsworth mentioned some weaknesses in the present "system" pointing out that it had been implied that NAL, NLM, and LC constituted a national library system but that such a system had not yet really been discussed, that he did not know what it is, or even whether "we are ready to talk about it yet." For example, he deplored the fact that, although the library community realized full well that LC would have to have catalogers if it were to carry out a centralized cataloging program successfully, other libraries were not ready to give up staff.

The "lack of a great university in Washington is another weakness," Mr. Ellsworth thought. "A great library can thrive only if there is constant interchange with first-rate scholars," he said. LC has scholars on its staff and many scholarly users, but a great university and a great library school would stimulate it.

Finally, he pointed out that time is required to build a tradition for a national-library system. "LC's relations with ARL have become quite intimate, but interaction with the Office of Education and the National Science Foundation, for example, is necessary. The Center for Research Libraries in relation to the national scene hasn't really jelled," he said. Fur- thermore, the "multiversity" of library organizations and kinds of thinking is also a problem, he concluded.

Dr. Martin M. Cummings (National Library of Medicine) was given "equal time." $\mathrm{He}$ expressed surprise at the attitude that motherhood is great and all is good. "As a physician and a political scientist I'm interested in motherhood," he said, "but I am also interested in fatherhood. One of the most essential ingredients is that we must not only have central resources but resources to share with others. Politically, I don't believe that in the Legislative Branch one can look forward to the support necessary. I believe that a lot of thought must be given to the organizational posture. You've got to know your father. The relationship of LC with other libraries and especially with other federal libraries is quite important," he felt.

In discussion from the floor, Keyes D. Metcalf (librarian emeritus, Harvard) advocated a national library system, particularly in regard to retrospective materials. "Publication of the pre1956 National Union Catalog will do a great deal to help, but the research libraries haven't the money to make their resources nationally available. If the federal government would pay a reasonable share of interlibrary services, this would be a long step forward," he said.

Title III of the Library Services and Construction Act provides support for interlibrary cooperation, John G. Lorenz (LC), pointed out. "We may be ready for a national library system conference," he said, and the ARL, ALA, SLA, MLA, ete., should be brought into such a conference, in which the National Advisory Commission on Libraries might well take the lead.

Frederick H. Wagman (University of Michigan) sounded a note of warning. "I get confused when I hear about national library systems," he said. "I'm afraid we expect something magical about the word 'system.' The great problem is that we do not define our terms: Nobody understands or agrees on what we mean by a 'national library system.' If there is to be a conference on a national library system, it should be very carefully planned; working groups should be formed and real studies produced in advance if we are to expect results." Mr. Bryant expressed the opinion that the timing for a conference was wrong.

Verner W. Clapp (Council on Library Resources) admonished the group that the meeting was to deal with the national library, but "now we are running off after the hare, "system." "He urged that the ARL Board meet again and take action "on a few minor things": (1) Improvement of photographic services; (2) the quality control of cataloging ("timeliness has been the main push and with Title II-C this is beginning to be realized, but now we 
should look into quality"); (3) decentralization of centralized cataloging; (4) LC's willingness to perform national-library functions (if the field supports them) has been expressed, and the ARL must do its share in making Congress feel the need for such services.

Proposed Change in aRL Bylaws

Before closing the afternoon meeting, President Rogers brought up a proposed change in the ARL Bylaws concerning the election of the president.

Change in Bylaws Article V, Sections 1, 2, 3, and 4 will read as follows:

ARTrCLE V-Nominations and Elections.

Section 1-Elections of the Board

There shall be a nominating committee of three persons; one to be the Vice-President who shall serve as chairman of the Nominating Committee; and two persons to be appointed annually by the President of the Association to the Board of Directors.

\section{Section 2-Nominations}

It shall be the duty of the Nominating Conmittee to select a slate of five nominees for the Board of Directors. No Director, having served a full three-year term, may be nominated to succeed himself. The consent of the candidates to serve if elected must be obtained before nominations are accepted. The report of the nominating committee shall be distributed to the members at least thirty days before the election.

Additional nominations may be made from the floor.

\section{Section 3-Elections of the Board}

Each member may vote for not more than three nominees, except for the election of a successor for an unexpired term.

The three candidates with the highest number of votes shall become members of the Board for three year terms.

Section 4 Election of the Vice-President

The Vice-President (President elect) shall be chosen from members of the Board and shall be elected by a majority vote of the Board of Directors.

The change was moved and seconded. It was passed unanimously.

It was moved, seconded and carried unanimously that henceforth the dinner at the semiannual meeting be an expense of the association.

Printed reports were circulated but not read.

L. Quincy Mumford (Library of Congress) called attention to the analysis of the Title II $\mathrm{C}$ program which was clistributed to the membership.

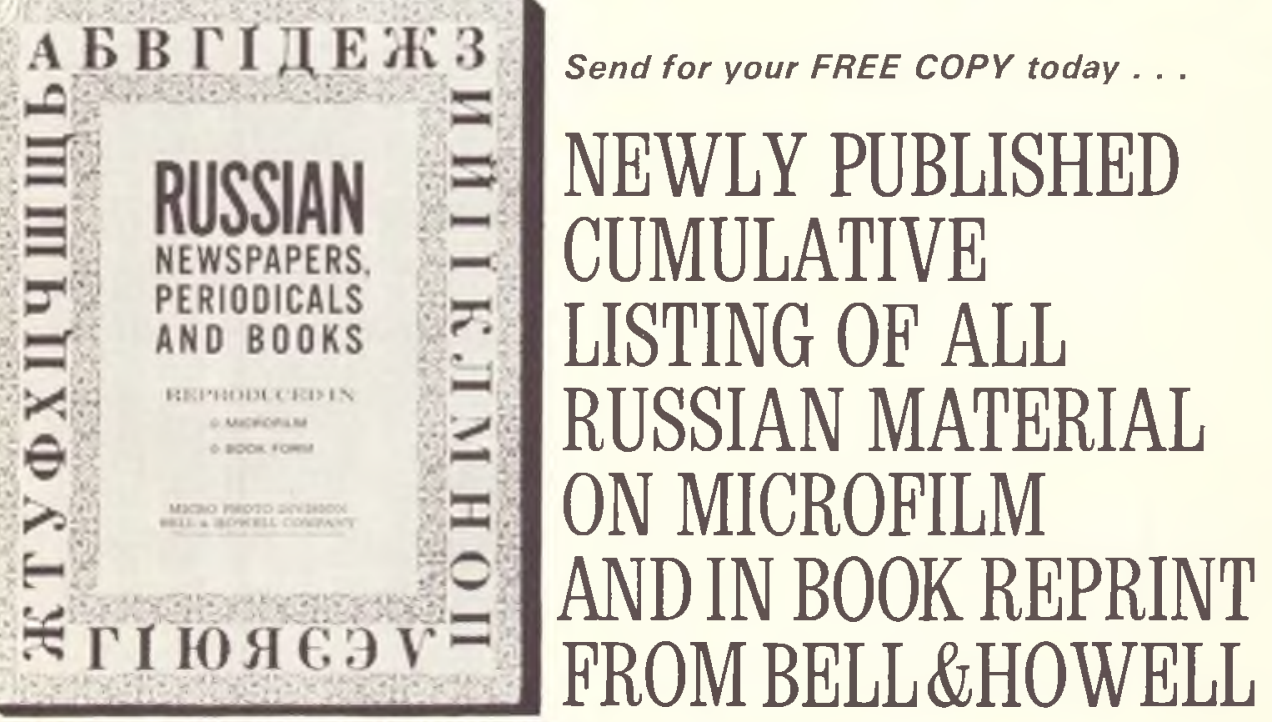

mICRO PHOTO DIVISION

1700 SHAW AVE. CLEVELAND, OHIO 44112

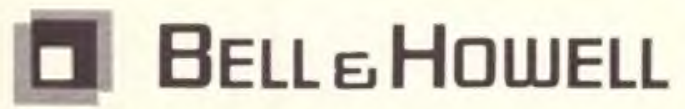

INCLUDED ARE:

- Russian Newspapers

- Russian Periodicals

- Russian-Language Books

- Russian Books in Western Languages 
National Library of Medicine "Fair Use." Martin M. Cummings (National Library of Medicine) read from his report concerning the challenge to the usual definition of "fair use" as followed by National Library of Medicine. The challenge by Williams and Wilkins may not be pressed.

Counsel to National Library of Medicine does not think that fair use has been violated. It was, however, indicated that some less protected library might become the target.

It was moved, seconded, and carried to support the position of the National Library of Medicine.

It was the sentiment of the meeting to support any library that was the victim of suit on fair use by Williams and Wilkins.

Mr. Cummings also read a statement later given to the press expressing the commitment to cooperation by the Library of Congress, National Agricultural Library, and National Library of Medicine.

The meeting adjourned for cocktails and dinner.

\section{Testimonial to Verner IV. Clapp}

As the dinner drew to a close, ARL President Rogers rose to make a special presentation. It was a tribute, dated June 24,1967 , and beautifully printed by the Spiral Press, from the ARL to Mr. Clapp. It read:

TO VERNER WARREN CLAPP, for more than fortyfive years of selfless dedication to the cause of librarianship and the service of scholarship, the Association of Research Libraries offers its sincere gratitude, affection and admiration. Polymath and sage, chronicler of the past and seer of the future, counselor to the United Nations and to foreign governments, advisor to library organizations, to scholarly associations and to countless libraries, his influence both nationally and internationally has been immeasurable. As librarian to the international conference that established the United Nations he served as the chief intermediary between the human record and the representatives of the nations of the world, dependent on that record for one of the most important undertakings in history. As planner and chief administrator of a vast national project he aided the research libraries of the nation in overcoming the deficiencies in their scholarly resources caused by the Second World War. As trusted advisor to the Japanese Government he was instrumental in the establishment, and in planning the organization of, the National Diet Library. As Chief Assistant Librarian of Congress for nine years he helped that institution earn its recognition as a great National Library. As President of the Council of Library Resources, Inc., he has for ten years translated the willingness of a great Foundation to serve the needs of research libraries into a comprehensive series of research projects and supportive undertakings that have yielded more fruitful analyses and more reliable data for planning present and future library work than had been produced in the entire prior history of research librarianship. As an honored spokesman for the library profession, trusted by humanists, scientists, educators and officials of government, he has faithfully and eloquently represented the ideals, needs and problems of research libraries to the public. As a devoted friend of libraries and librarians he has spared neither his energies nor his health in working for the improvement of the profession and in aiding any librarian who asked for assistance. No man of our time has had a more beneficent or broader influence on research librarianship. For a lifetime of devoted and productive service to librarianship and scholarship, the Association of $\mathrm{Re}$ search Libraries, at this its seventieth meeting, honors both itself and Verner W. Clapp by conferring upon him the title of

\section{LIBRARIAN'S LIBRARIAN}

and by admitting him to all rights, perquisites and responsibilities of that status.

This was greeted by prolonged, appreciative applause on the part of the audience and by a brief, self-depreciating, but grateful response on the part of the recipient-for once left speechless.

The ARL reconvened for the business meeting at 7:30 P.M.

Chemical Abstracts Services: Herman R. Henkle (John Crerar library) reported for the Special Committee on Relations with Chemical Abstract Services. He indicated the unhappiness of libraries which check holdings of CAS at cost of from $\$ 2,500$ to $\$ 5,000$.

Fred A. Tate, assistant director of Chemical Abstracts Services, explained the method of production of the Abstracts and indicated that the present checking would be the last of its kind.

Many questions were asked of Mr. Tate. The progress toward a world list of serials and its relation to CAS was again brought up by Frederick H. Wagman (University of Michigan). Robert H. Blackburn (University of Toronto) asked why so many libraries had to report. Mr. Tate allowed that sixteen might be enough.

Mr. Rogers said it was the state of affairs that small libraries liked the checking while larger ones do not.

Mr. Carl Hintz (University of Oregon) asked what would happen to CAS if no one checked. Mr. Tate, "We die."

The Association approved Mr. Henkle's report of the objections of the members who check holdings for the Chemical Society at considerable expense and continue to pay the increasing prices for the Abstracts. Mr. Tate reported that the circulation was about 7,000 . One-half of the subscribers are from industry, the rest are from universities and government agencies. Mr. Dix asked what could be done to come to terms with CAS to settle the unhappy situation. Mr. Tate said that CAS was willing to appoint a member of ARL to a CAS library panel.

Report of the President. President Rogers reported for the Board of Directors.

Stephen A. McCarthy expects to assume the duties of Executive Director on November 1. Progress was reported toward establishing the Center for Mainland China Material Resources. Application is in progress for estab- 
lishing an Eastern European Bibliographical Center.

Executive Director's Report. Mr. Cameron paid special tribute to the librarian of Congress and others at LC concerned with Congressional liaison. He also thanked Mr. Skipper and Mr. Clapp for the help they had given him. He reported that, although fringe benefits are difficult to establish, salary statistics would be published by the first of August, whether complete or not. He also said that a survey of the success of applications for grants under Title II is under consideration because it is felt that even information on unsuccessful applications would be helpful to ARL members.

Because detailed reports by the three national libraries and committee reports were distributed to members in advance of the business meeting, oral reports were dispensed with. Mr. Clapp reported briefly on copyright revision. He indicated that librarians had not been vocal in the debates on the contemplated revisions. The question to which there was no direct answer was, "Should ARL have a copyright committee?"

It was announced that the next meeting would be on January 7 at 2:00 P.M., at the Americana Hotel in Bal Harbour, Fla.

The meeting was adjourned at 9:00 P.M.Donald F. Cameron, Executive Director.

\section{FOR THE RUSSIAN BOOK SECTION}

\section{Reference and}

Source Material

- Russian Literature: Classics, Contemporary

- Linguistics and Literary Criticism

- English-Russian and Russian-English Dictionaries

- Russian Language Records

- Children's Literature

- Books on Art

- Books on Science

- Textbooks on mathematics, geography, natural sciences, history, etc.

- Socio-Economic Literature

- Russian Atlases and Maps

- Soviet Magazines and Newspapers

Inquire about our out-of-print books and back issue magazines.

Write for Catalogs \& Prices

Phone 212 CH 2-4500

FOUR CONTINENT BOOK GORP. DEPT. 727,156 FIFTH AVENUE, NEW YORK, N. Y. 10010

The WHAT,

WHERE, WHEN,

WHY, and HOW

of

LIBRARY
SURVEYS

Edited by

Maurice F. Tauber and Irlene R. Stephens

A group of outstanding contrib. utors from library schools and libraries explain the value, effectiveness, and use of the library survey as an aid to planning and improving services.

They show the application of surveys to all aspects of library operation (book collection, processing, use of library resources and facilities, and library administration), and to all types of libraries (academic and research. public, school, special, and state).

The book is a useful tool both for survey and for library administrators considering having a survey done or wishing to do one themselves.

$\$ 13,50$

The life and times of a great librarian-

\section{LOUIS}

ROUND WILSON

LIBRARIAN AND ADMINISTRATOR

A biography by

Maurice F. Tauber

$\$ 8.50$

COLUMBIA

UNIVERSITY PRESS 